\title{
悪性疾患患者における T細胞の動態
}

一特に胃癌患者を中心として一

\section{東京医科大学外科学第 3 講座（指導教授：牧野惟義）}

助手 長 田 省一

\author{
THE CHANGE OF THE RATIO OF T-CELL IN PATIENTS \\ OF MALIGNANT DISEASES \\ -ESPECIALLY IN THE GASTRIC CANCER- \\ Shoichi NAGATA \\ Department of Surgery, Tokyo Medical College \\ (Director : Professor Koreyoshi Makino)
}

\begin{abstract}
悪性疾患患者において，盾瘄の発育・增大には，細胞性免疫能が関与している事は，最 近の免度学の進歩により，疑いのない事実とされている。この細胞性免疫能には， Tリン 八゙球・Bリンパ球・マクロフフーシを始め, 種々の免度担当細胞が関与しているが, その 主役をなするのは Tリンバ球である. 故に， T リンバ球の生体における变動は，悪性疾患 患者に批いて, 生死にかかわる問題である. そこで, 著者は, 胃癌患者を中心として, 悪 性疾患患者の予後を推定すべく, 患者の末梢血より，リンパ球を分離し，T-cel ・ B-cell の識別を行い，種々の面から険討を加えた。

T-cel ・ B-cell の識別法は, Conray Fi-Coll による此重遠心法にて, 末梢血よりリンパ 球を分離し，ヒッジ赤血球と T-cell, 補体感作ヒツジ赤血球と B-cell を反応させ, 鏡検 にて, rosette formation を観察し, 判定した。

その結果, 悪性疾患症例に批いて, 経過良好症例の T-cel 值は, 健康人之同様, 良好 な值を示した．一方，悪液質に陥った症例での検査値では，著明な低下か認められた。 た，手術施行例での術前検査值は，手術根治度の低下とともに T-cell 值も低下し, B-cell

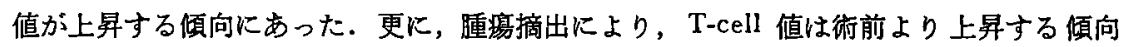
がみられたが，特に，治滃切除例では，健康人之同程度まで回復する症例が多かった．ま た, 胃癌術後 5 年以上を経過した長期生存例では, 㛟索したすべての症例で健康人上同等 の值が認められた.

以上の事から,T-cell • B-cell の値を経時的に観察する事は, 悪性疾患患者の予後判定 に有意義であるとの結論を得た。
\end{abstract}

\section{I. 緒 言}

近年, 腫瘍免疫学は著しい進歩を示し，悪性疾患患者 においても，腫湯の発育・進展・転㷌飞は，免度現象が 閔与している事は，既定の事実として認められており， 悪性鲝痬に対する免疫療法を提唱する研究者に扎いて， 大きな関心事として取り組まれている。
本来, 免疫反応とは生体が自己と非自己を識別し，非 自己を抗原として認識したのち，特異的に抗体を 産生 し，これを処理する一連の連鎖的反応である”．今日， この免疫反応は，体液性免疫と細胞性免疫の 2 つに大別 されている。

悪性腫湯患者において，正常の生体内には本来存在し 
ない腫瘍細胞が，殆んど拒絶される事なく，発育・進展 していく過程では，生体が異種抗原の認識を行い，それ を排除する細胞性免疫能か低下しているためと，考克ら れている。この細胞性免疫機構の発現には, $\mathrm{T}$ リンハ 球・Bリンパ・マクロファージ等の免疫担当細胞が相互 に複雑に作用しあっていると考古られている。それれらの 細胞のらち，いずれの細胞が機能低下・変性しても腫場 の発育・增大・転移を阻止する事はできないが，なか でるこれらの主役をなしているすのが リンパ球で ある.このTリンパ球は, helper T-cell; killer T-cell, suppressor T-cell として，また、リンフォカインを産生 する事により，本来，正常生体内に存在しない物質を異 物として認識し免废機構を維持している。これら種々の 働きをなすT-cell が B-cell やマクロファージを刺敨， 活性化する事により, 細胞性免疫能, 即ち, 尰瘍免疫能

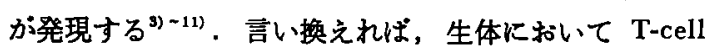
の機能が低下している㗫には，その生体は，体内に発生 した悪性新生物を排除する事ができず，隀晹死一向かっ ていくと考えられる.

以上の事を踏ま之て，著者は悪性疾患患者の末梢血》 ンバ球に打ける T-cell の割合を释時的汇観察した。こ の事は，悪性疾患患者の予後を推定するととすに，免疫 療法，化学療法を行う際に臨床的に有意義であると考 之, 胃癌患者を中心として, リン八球の $\mathrm{T}, \mathrm{B}$ 細胞比を 識別し，予後判定の一助とすへくく，種々の面から検討を 加えた.

\section{II. 研究対象及び方法}

\section{1. 样查対象（表 1)}

検査対象は以下の項目に分類し検索を行なった，各疾 患群の症例数及び検体数は表 1 の如くである.

1) 煡康人

何等の病的愁訴のない成人男女16人を無作為的に選択 し， 1 人 $1 \sim 3$ 回, 合計 30 回の検索を行い, その平均值

\section{表 1 検查症例内訳}

\begin{tabular}{|c|c|c|}
\hline (5) & 症 例 数 & 検 体数 \\
\hline 健 康 人 & 16 & 30 \\
\hline 良 性 疾 患 & 54 & 66 \\
\hline $\begin{array}{ll}\text { 胃 㾇 } \\
\end{array}$ & 151 & 329 \\
\hline 胃癌以外の癌 & 121 & 238 \\
\hline 計 & 342 & 663 \\
\hline
\end{tabular}

表 2 良性疾费検查症例内訳

（）黄㾝陽性

\begin{tabular}{|c|c|c|}
\hline 疾 & 症例数 & 换 体 数 \\
\hline 同洪的 & $15(3)$ & $21(3)$ \\
\hline 目炎・ボリーブ & 5 & 5 \\
\hline 肝资 - 肝硬变 & $6(6)$ & $10(7)$ \\
\hline 石 & 2 & 2 \\
\hline 旰・滕のう胵 & 2 & 2 \\
\hline 沉発性胶膜炎 & $6(2)$ & $6(2)$ \\
\hline 釈腺炎 - 乳䏮症 & 3 & 4 \\
\hline 肺资・気管支资 & 3 & 4 \\
\hline リンハ腺掞 & 3 & 3 \\
\hline 大臑良性疾息 & 3 & 3 \\
\hline 甲 状 脸 胵 & 2 & 2 \\
\hline 心 疾 患 & 2 & 2 \\
\hline 皮フ梅毒 & 1 & 1 \\
\hline 子宮 筋 㥀里 & 1 & 1 \\
\hline 鼓 & 54 (11) & $66(12)$ \\
\hline
\end{tabular}

表 3 䁌空梌查症例内訳

（）检体数

\begin{tabular}{|c|c|c|c|c|c|c|}
\hline & 治䇥切除 & 非治貝切操 & 如播不能 & 手術せず & 再 & it \\
\hline 柽道良好 & $37(78)$ & $20(57)$ & 0 & 0 & 0 & $57(133)$ \\
\hline 覀湾筷 & $1(3)$ & $28(88)$ & 24 (38) & $11(20)$ & $2(5)$ & $66(154)$ \\
\hline 不 变 & $2(5)$ & $8(15)$ & $2(3)$ & $1(2)$ & 0 & $13(25)$ \\
\hline 長期生存 & $13(13)$ & $2(2)$ & 0 & 0 & 0 & $15(15)$ \\
\hline 訲 & $53(101)$ & $58(162)$ & $26(41)$ & $12(22)$ & $2(5)$ & $151(329)$ \\
\hline
\end{tabular}

を正常値とした。

\section{2）息性疾患（表 2)}

表 2 に示す如く，胃潰瘍15症例21榆体を中心に検索を 行い，悪性疾患症例之対比した。 また，各疾患は黄疸の 有無, 及び, 沉発性腹膜资症例については, 別に検討を 加えた.

3）胃癌症例（表 3)

胃癌症例は，早期癌や術後長期生存例を含め，151症 例329検体に検索を加えた。これら症例を，経過良好症 例と悪液澌症例との比較，手術根治度別にみた検査值の 相違，手術前後の検查値の変動及び，長期生存例につい 


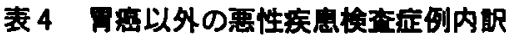

（）㭘体数

\begin{tabular}{|c|c|c|c|c|}
\hline 疾 & 経通良好 & 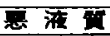 & 不 变 & It \\
\hline 大 & $16(31)$ & $10(28)$ & $7(12)$ & $33(76)$ \\
\hline 趾 & 10 (21) & $4(10)$ & $4(5)$ & $18(36)$ \\
\hline 胡 & $5(13)$ & 11 (19) & $3(4)$ & $19(36)$ \\
\hline 腰 & $2(5)$ & $9(13)$ & $3(4)$ & $14(22)$ \\
\hline 肉 盟 & $3(4)$ & $3(6)$ & 1 (2) & $7(12)$ \\
\hline 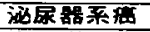 & $4(9)$ & 0 & $2(3)$ & $6(12)$ \\
\hline I II 豞 & 0 & $5(11)$ & $1(2)$ & $6(13)$ \\
\hline 胆 $\sigma う$ 婹 & 0 & $4(7)$ & 0 & $4(7)$ \\
\hline 用 酒 & 0 & $2(4)$ & $1(1)$ & $3(5)$ \\
\hline 甲状田要 & $2(3)$ & 0 & $1(2)$ & $3(5)$ \\
\hline 子䆓 㤎 & 0 & $2(4)$ & 1 (1) & $3(5)$ \\
\hline 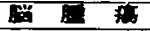 & $\mathbf{0}$ & $1(2)$ & $1(t)$ & $2(3)$ \\
\hline 上因頭僄 & 0 & 0 & $1(3)$ & (3) \\
\hline 皮 フ 成 & 0 & 0 & $1(2)$ & $1(2)$ \\
\hline 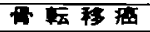 & 0 & $1(1)$ & 0 & $1(1)$ \\
\hline st & $42(91)$ & $52(105)$ & $27(42)$ & $121(238)$ \\
\hline
\end{tabular}

て検討を加えたななお，経過良好症例とは，手術施行 後，自覚症状が消失し臨床的に全身状態の改善をみた症 例をもってその範嵭とした。

\section{4）胃癌以外の悪性疾患（表 4)}

胃癌以外の覀性疾患は表 4 の如く，121症例238検体に ついて検索した．これら症例は胃癌症例同様，経過良好 症例と悪液質症例との比較，手術根治度別にみた術前検 査値, 手術前後の検査值の変動について検討した.

2. 使用材料

1）末梢血

検查当日，患者上腕よりへパリソ加注射器にて，静脈 血 $2 \mathrm{ml}$ を採血して用いた。

2）ヒトリンパ球識別用 $\mathrm{T}$ 細胞， $\mathrm{B}$ 細胞微量湘定用 $\neq$ ッ卜 (日本抗体研究所製)

末梢血より，リンパ球を分離し，T-cell とヒッジ赤血 球との特異的反底，B-cell と補体感作ヒツジ赤血球との 補体結合反応，更に，混入した単球，幼若顆粒球を識別 する為のペルオキシダーゼ反応を行い， T-cell, B-cell の識別を行う行程に用いた

\section{3.リンパ球分離法（図 1 )}

リンパ球の分離は比重遠心法にて行なった。一パリン 加末梢血 $2 \mathrm{ml}$ に, $10 \%$ Phosphate Bufferd Saline(P.B.S) を等量加え，倍数希釈した検体を比重 1,077 リンパ球 分離試薬 Sodium Meto-rizoate Fi-Coll 混夜 (S.M.F) $3 \mathrm{ml}$ 上に，静かに注入，重層し30分遠心した。これに より，比重の大きい赤血球及び，顆粒球は最下層へ沈没 し，血漿成分は上㬝に浮遊．その中間にリンパ球膡を得 た。遠心後，最上層にある血獎成分をメスピベットにて 排除し，中間凮にあるリンパ球分画を他のメスピペット にて別の試験管に集めた。このリンパ球分画に充分量の
图 1 実跧方法

ヘバリン加末梢血 2c.c.

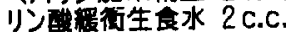
$\downarrow$ (PBS)

Conray Ficoll ( 3 c.c.) に遠沈 $\downarrow \quad 400 \times \mathrm{g}$

PBSにてリンハ球屋洗净 3回 $\downarrow$

リンパ球浫遊湾 $1 \times 10^{6}$ 個 $/ \mathrm{mL}$
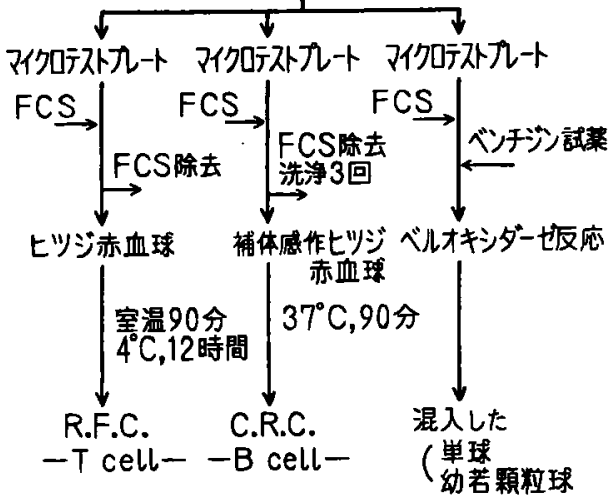

PBS を加え，バラフィルムで封じ，試験管を転倒混和 したのち，240g にて10分遠心した.これにより，リン ハ球層を最下層へ落しリンパ球分画採取の踏，一緒に採 取された血小板や血脽成分を上澄として除去した．更に 不純物を除去するため,リンパ球の洗浄を行なった。即 ち，リンパ球が底に附着した試験管をフラッシュミキサ 一にかけ，リンパ球ペレットを擋拌分離し，充分量の PBS を加光，遠心器にかけた。この洗浄のための遠心 は $100 \mathrm{~g}$ Kて10分行い，上澄を除去したのち，更にすら 1 度洗浄し，合計 3 回のリンバ球洗浄を行い，末梢血よ ク，リンパ球を分離獲得した。

\section{T-cell, B-cell 㦈別法}

分離したリンバ球は, T-cell とヒツジ赤血球との特異 的反応，B-cell と補体感作ヒッジ赤血球との補体結合 反応を行い，両細胞の識別を行なった。更に混入した単 球・幼若顆粒球についてはペルオキシダーゼ反応にて識 別し, T-cell・B-cell と判別した.

1) リンパ球数の調整

末梢血より分離したリンパ球浮遊液を白血球計数盤に て count し，浮遊液濃度が $1 \times 10^{6}$ 個 $/ \mathrm{ml}$ となるように PBS を加えた。

2）補体感作ヒツジ赤血球の洗浄

補体感作ヒツジ赤血球は溶血を起しやすいため PBS にて洗淮し，溶血した赤血球を除去したのち，リンハ球 と反応させた. 赤血球浮遊液をメスピペットにて小試験 
管に移し，3ml の PBS を加克，800〜900g にて10分遠 心した。これにより，赤血球は試験管底に沈澱し，上澄 の不純物を除去した，遠心後，上澄を除去した試耠管底 の赤血球ペレットは, フラッシュミキサーにて擋拌分離 し, PBS $1 \mathrm{ml}$ に再浮遊させた。

3）リンパ球のマイクロテストプレート滴下 $1 \times 10^{\circ}$ 個 $/ \mathrm{ml}$ に調整したリンバ球浮遊液を T-cell 判定用・Bcell 判定用・ペルオキシダーゼ反応用の3枚のマイクロ テストブレートの各孔に滴下・附着させた.この際, フ レート内を乾燥させると，微量のリンバ球浮遊液を蒸発 する恐れがあるので，プレートの辺緑汇あらかしめ濾紙 を數き，PBS にて充分の湿気を与えた，その後，プレ ートの各孔に $25 \mu 1$ 用マイクロシリンジにて $1 \mu 1$ ずつ, リンハ球浮遊液を加えた，すべての娭体を各孔に加えた のち,プレートKふたをして乾燥を防ぎ，15分間室温に て放置し，浮遊夜を孔内に安定させた．

4）テストプレートの PLL ブロック

15分間放置した 3 枚のマイクロテストブレートに，牛 胎児血清 Fetal Calf Serum (F.C.S) を加え,プレート 孔表面の Poly-L-lysine (P.L.L)をブロックし，以後の 反応をスムーズ行なわせた。ペルオキジダーゼ反応用 のプレートは, rosette formation の必要がないので FCS す少量で,ブロック時間も短時間で行なった. 即ち、へ

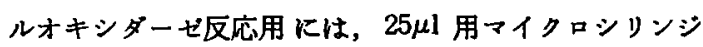

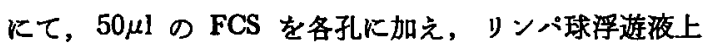
部より PLLをブロックし，15分間室温に放置した，T

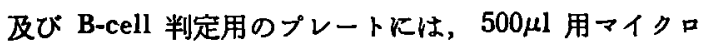
シリンジ10 1 の FCS を加光，30分間室温に放置し，

PLL をプロックした.

5) プレート孔の洗浄

B-cell 判定用のプレートに加えた FCS は補体結合反 応汇よる B-cell の rosette formation を阻害するため, ブレート孔を PBS にて洗净し FCSを排除した，PLL ブロックを終えたテストプレート各孔の FCS を，TAC 式トランペット管を用いて除去した。 その後, 各孔に PBS を TAC 式マイクロ分注器にて孔の上部に盛りあ げ，静かに反転し PBS ととすに，孔残った FCSを 再びトランペット管にて除去した。この洗浄操作を更 にもら1回行い，FCS をできるだけ除去するよらに努 めた. T-cell 判定用のプレートは, FCS が, T-cell の rosette formation を障害しないため，特にプレート孔の 洗浄は必要なく，孔表面の FCS を除去し，洗浄は施行 しなかつた。
6）リンパ球とヒツジ赤血球・補体感作ヒツジ赤血球 との反応

ヒッジ赤血球・補体感作ヒツジ赤血球を，それそれれ 各々の条件下で，T-cell，B-cell と反応させ， rosette formation を行なわせた.

FCS を除去した T-cell 判定用ブレートにはヒッジ赤 血球を, B-cell 判定用プレートには補体感作ヒツジ赤血

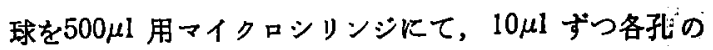
リンパ球浮遊液上に滴下した. T-cell 判定用のブレート は, 室温にて90分放置したのち， $4^{\circ} \mathrm{C}$ 低温下゙に一晚 放置し、T-cell とヒッジ赤血球の反応を行なわせた。 B-cell 判定用のプレートは, $37^{\circ} \mathrm{C}$ 恒常保温器内でプレ 一ト正置で60分放置し，B-cell と補体感作ヒッジ赤血球 に補体結合反応を行わせ, 30 分問プレート倒置後, 以後 の操作を行なった。

7） T-cell, B-cell 判定用マイクロテストプレートの 固定染色

rosette formation を行なった陽性細胞数を顕徽鏡下に て判定するために固定染色を行なった即ち，各々の条件 下にて反応させたテストプレートを，PBS を䩗たした シャーレに静かに漫し，斜めに倒圆した状熊で15分間放 直し，孔表面の余分な赤血球浮遊液を除去した. その孔 内に残った PBS を除去し， BCB 色素配合タルタール フルデヒド察液を各孔に滴下し, 固定染色した。

8）ペルオキシダーゼ反応用マイクロテストブレート の反応及び染色

FCS を加え室温に放置して批いたベルオキシダーゼ 反応用のプレートは，ただちにドライヤーにて暲燥さ せ、ペルオキシダーセ溶液を各孔にパスッールピペット にて滴下し，30６0秒反応させた. その後, 更に蒸留水 を滴下しペルオキシダーセ溶液を希釉し，4分間放置後 プレート孔を洗浄し，10倍希釈した BCB 色素配合タル タールアルデヒド溶液を滴下・染色して鏡検にて判定し た.

\section{5. 検查判定法}

T-cell 及び B-cell 判定用プレートは, 光学顕徽鏡に て200倍で rosette formation を行なった陽性細胞数を count した. ヒッジ赤血球, 補体感作ヒッジ赤血球が 4 個以上反応したリンハ球を rosette formation 陽性細胞 とした（写真 1)。ペルオキシダーゼ反応陽性紐胞は， プレート孔内の他の細胞（すなわちリンパ球）に比し， 細胞質内黄裼色に染色ざれた顆粒が認められる。な

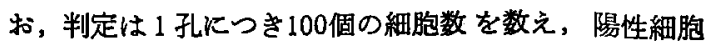


写共 1

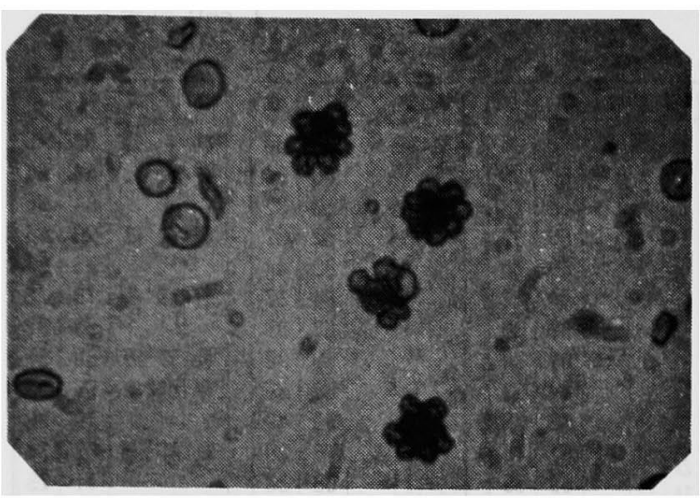

数の割合を求めた．また， count は 1 検体につき 5 孔行 い,その平均値を検査結果とした。

\section{III. 検查結果}

\section{1. 侓廉人（表 5)}

健康人 16 症例 30 検体に打ける㭘查結果は，T-cell 57〜 71， B-cell 26〜49の範囲にあり，その平均値は T-cell

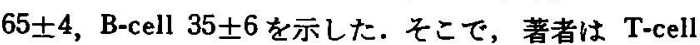
65，B-cell 35を正常値として以下の検査結果の対照とし

表 5 健康人正常值

\begin{tabular}{|l|c|c|}
\hline \multicolumn{1}{|c|}{ T-cell } & B-cell \\
\hline 告 & $60 \sim 70$ & $30 \sim 50$ \\
\hline D.Ross & $40 \sim 60$ & $20 \sim 30$ \\
\hline C.William & $75 \pm 15$ & 35 \\
\hline J.Wybran & $62 \sim 73$ & \\
\hline $\begin{array}{c}\text { 東 京 医 大 } \\
\text { 平均標準偏差值 }\end{array}$ & $\begin{array}{c}57 \sim 71 \\
65 \pm 4\end{array}$ & $\begin{array}{c}26 \sim 49 \\
35 \pm 6\end{array}$ \\
\hline
\end{tabular}

表 6 良性疾患模查結果

（）検体数

\begin{tabular}{|c|c|c|c|c|c|c|}
\hline 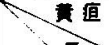 & 费 & 百 & 性 & (*) & 㨁 & 性 \\
\hline - & 在闻 & $T$ & B & 应的 & $T$ & B \\
\hline 目良性矣 & $20(23)$ & $65 \pm 4$ & $35 \pm 6$ & $3(3)$ & $56 \pm 2$ & $41 \pm 2$ \\
\hline 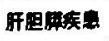 & $7(7)$ & $65 \pm 4$ & $32 \pm 4$ & $6(7)$ & $53 \pm 10$ & $45 \pm 9$ \\
\hline 沉琶性 & $4(4)$ & $58 \pm 6$ & $44 \pm 5$ & $2(2)$ & $56 \pm 11$ & $47 \pm 10$ \\
\hline その他 & $18(20)$ & $64 \pm 6$ & $36 \pm 5$ & 0 & & \\
\hline हैं & $49(54)$ & $64 \pm 5$ & $36 \pm 7$ & $11(12)$ & $55 \pm 8$ & $43 \pm 8$ \\
\hline
\end{tabular}

た.

\section{2. 良性疾悤症例（表 6）}

胃潰晹を中心として種々の良性疾患患者を検索した結 果, 黄疸の有無により有意の差を認めたため, 黄疾陰性 症例と黄疾陽珄症例とに大別し，その平均値を表 6 に示 した。なお，本表には胃溃場術後黄疾の治空した 3 症例 及び, 肝炎の治淕した 3 症例が黄㡺陰性, 黄疸陽性相方 に症例数として加えられており重襀している.

1) 黄疸陰性症例

術後黄疾の治空した胃潰瘍 3 症例 3 検体を含む胃良性 疾患20症例 23 検体の検査結果は, T-cell $65 \pm 4$, B-cell $35 \pm 6$ と健康人と同様の值を示した. 黄疸の治疬した肝 炎 3 症例 3 検体を含む肝胆道系良性疾患 7 症例 7 検体に おりる平均值は T-cell $65 \pm 4$, B-cell $32 \pm 4$ と, ここ でも健康人と同様の值がみられた。次に，沉発性腹膜炎 を併発した十二指晹潰瘍穿孔 3 症例 3 恰体，虫垂炎穿孔 1 症例 1 検体の計 4 症例 4 検体の平均值は，T-cell 58土 6, B-cell $44 \pm 5$ と趾康人に比し, T-cell が低下し Bcell か上昇する傾向が認められた。その他，表 2 に示 した種々の良性疾患 18 症例20検体に打ける検査結果は, T-cell $64 \pm 6$, B-cell $36 \pm 5$ と健康人と同様の值であっ た.

以上，黄病を認めなかった良性疾患49症例54検体に扣 いて沉発性腹膜咨症例で $\mathrm{T}$-cell 低下, B-cell 上昇の傾 向を認めたものの，全症例での平均值は T-cell $64 \pm 5$, B-cell $36 \pm 7$ と良好な值であった。

2）黄㡺陽性症例

一方，良性疾槵で黄㾝発症時の症例について検索した 結果は, 胃溃場術後に肝炎を併発した 3 症例 3 検体で T-cell $56 \pm 2 ，$ B-cell $41 \pm 2$ と健康人に比し T-cell 低下し，B-cell が上昇している事が認められた。また， 黄疸か認如られた肝炎 3 症例 3 検体, 肝硬変 3 症例 4 検 体の計 6 症例 7 検体の 平均值は T-cell $53 \pm 10$, B-cell $45 \pm 9$ と、ここです T-cell 低下，B-cell 上昇を認めた。 次に，黄㾝を併発した十二指腸潰湟穿孔及び胃潰湯穿孔 各 1 症例 1 検体ずつの沉発性腹膜炎患者の検查結果は, T-cell 56 \pm 11 , B-cell $47 \pm 10$ と T-cell の低下, B-cell の上昇を認めた。

これら黄㾝併発11症例12検体の平均値は，T-cell 55士 8, B-cell $43 \pm 8$ と, T-cell 低下, B-cell 上昇の㑯向を 示した。しかし，沉発性腹膜炎症例では黄疸の有無にか かわらず，T-cell 低下，B-cell 上昇を認めた。

\section{3. 恵性疾患経過良好症例}


表 7 経過良好退院例一胃痁一 全平均 T cell $65 \pm 5$

\begin{tabular}{|c|c|c|c|c|c|c|c|c|}
\hline 治雷切瞵 & $T$ & B & 治蹰切除 & $T$ & B & 非治空切除 & $T$ & B \\
\hline 早散离 & 74 & 24 & Stage II & 66 & 34 & Stage III & 61 & 40 \\
\hline$"$ & 67 & 33 & " II & 57 & 46 & " III & 70 & 35 \\
\hline$"$ & 62 & 42 & " II & 52 & 49 & III & 63 & 40 \\
\hline$"$ & 58 & 37 & II & 71 & 29 & III & 75 & 22 \\
\hline$"$ & 65 & 40 & II & 73 & 25 & III & 65 & 35 \\
\hline " & 56 & 40 & II & 64 & 36 & III & 67 & 33 \\
\hline$"$ & 56 & 31 & II & 66 & 34 & III & 68 & 32 \\
\hline$"$ & 65 & 38 & II & 63 & 36 & $\mathbf{N}$ & 60 & 46 \\
\hline$"$ & 62 & 38 & II & 63 & 35 & $\mathbf{N}$ & 68 & 30 \\
\hline$"$ & 70 & 33 & III & 71 & 30 & $\mathbf{N}$ & 63 & 40 \\
\hline " & 65 & 36 & III & 70 & 30 & $\mathbf{N}$ & 62 & 38 \\
\hline$"$ & 65 & 35 & III & 64 & 35 & $\mathbf{N}$ & 63 & 40 \\
\hline$"$ & 67 & 33 & III & 66 & 32 & $\mathbf{N}$ & 69 & 40 \\
\hline$"$ & 60 & 44 & III & 60 & 33 & $\mathbf{N}$ & 77 & 26 \\
\hline$"$ & 66 & 34 & III & 68 & 38 & $\mathbf{N}$ & 58 & 38 \\
\hline " & 53 & 44 & III & 68 & 31 & $\mathbf{N}$ & 64 & 36 \\
\hline$"$ & 69 & 31 & & 67 & 33 & $\mathbf{N}$ & 60 & 37 \\
\hline \multirow{4}{*}{\multicolumn{3}{|c|}{ 平场 $\begin{array}{l}T \text { cell } 64 \pm 5 \\
\mathrm{~B} \text { cell } 36 \pm 5\end{array}$}} & & 63 & 35 & $\mathbf{N}$ & 68 & 28 \\
\hline & & & & 69 & 21 & " & 62 & 42 \\
\hline & & & & & & & & 33 \\
\hline & & & \multicolumn{3}{|c|}{ 平均 $\begin{array}{l}T \text { cell } 65 \pm 5 \\
B \text { cell } 34 \pm 6\end{array}$} & \multicolumn{3}{|c|}{ 平的 $\begin{array}{l}T \text { cell } 66 \pm 5 \\
\mathrm{~B} \text { cell } 35 \pm 6\end{array}$} \\
\hline
\end{tabular}

悪性疾患症例は胃癌151症例329検体，胃癌以外の悪性 疾患121症例238検体について桧索した。そして，これを 程過泉好症例と悪液質症例之に大別し，更に各々を胃癌 と胃癌以外にわけ検討した。

1）胃癌症例（表 7)

手術施行後良好に経過し検索を行なった胃癌症例い， 早期癌症例が 17 例, 治瘾切除例が 20 例及び非治瘾切除症 例が20例の合計57症例であるが，これを各群にわけ平均 值を求めた。

\section{a) 早期胃癌}

早期胃癌17症例の個々における検查結果は，表 7 に示 したよらに，T-cell 56〜74，B-cell 24〜44の範围にあ ク，その平均值江 T-cell $64 \pm 5$, B-cell $36 \pm 5$ と健康 人同様の値であった。

b ) 治瘾切除

進行癌症例のらち, 治瘾切除が可能であった各症例の 值は, 表 7 の如く, T-cell 52 73, B-cell 27〜47の範 团で，平均値は T-cell $65 \pm 5 ，$ B-cell $34 \pm 6$ と，これ あ良好であった。

c) 非治疮切除

非治瘾切除に終った症例では，T-cell 58〜77，B-cell 22〜46の範囲で, その平均值は, T-cell $66 \pm 5$, B-cell $35 \pm 6$ と, ここでも, 健康人同様, 良好な值が得られ
表 8 経過良好退院例一胃窝以外の癌一 平均値 $\begin{aligned} & \mathrm{T} \text { cell } 65 \pm 6 \\ & \mathrm{~B} \text { cell } 34 \pm 6\end{aligned}$

\begin{tabular}{|c|c|c|c|c|c|c|c|}
\hline 疾息名 & $T$ & B & 疾 & 悬 & 8 & $\mathbf{T}$ & $\mathbf{B}$ \\
\hline 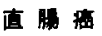 & 58 & 36 & 結 & A & 虹 & 64 & 36 \\
\hline " & 60 & 39 & & $"$ & & 65 & 34 \\
\hline ״ & 68 & 28 & 釈 & & 蝴 & 63 & 37 \\
\hline$"$ & 65 & 32 & & $"$ & & 62 & 32 \\
\hline$"$ & 69 & 34 & & $"$ & & 60 & 44 \\
\hline$"$ & 64 & 32 & & $"$ & & 64 & 32 \\
\hline " & 69 & 30 & & " & & 67 & 37 \\
\hline$"$ & 67 & 34 & & $"$ & & 60 & 39 \\
\hline$"$ & 67 & 37 & & " & & 63 & 36 \\
\hline$"$ & 65 & 35 & & " & & 59 & 40 \\
\hline 結渴病 & 57 & 45 & & $"$ & & 75 & 29 \\
\hline$"$ & 65 & 35 & & $"$ & & 68 & 30 \\
\hline$"$ & 74 & 30 & 肺 & & 渵 & 60 & 39 \\
\hline$"$ & 75 & 28 & & $"$ & & 65 & 39 \\
\hline
\end{tabular}

\begin{tabular}{|c|c|c|}
\hline 疾息各 & $T$ & B \\
\hline 肺怙 & 62 & 40 \\
\hline " & 64 & 36 \\
\hline$"$ & 64 & 36 \\
\hline 腄 䑏 我 & 70 & 33 \\
\hline$"$ & 75 & 21 \\
\hline 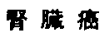 & 73 & 22 \\
\hline " & 53 & 37 \\
\hline 尿管度 & 58 & 37 \\
\hline 甲状腺症 & 59 & 38 \\
\hline " & 70 & 30 \\
\hline 縕網肉胿 & 62 & 34 \\
\hline " & 71 & 25 \\
\hline 回首部肉近 & 50 & 52 \\
\hline 陰蓄症 & 71 & 33 \\
\hline
\end{tabular}

た.

以上の如く，良好に経過した症例では，早期癌，治㾤 切除, 非治瘚切除ともに良好な值を示し, 全症例57例で の平均値も T-cell $65 \pm 5, \mathrm{~B}$-cell $35 \pm 5$ 之健康人同粎 の值であった.

2）胃癌以外の悪性疾患症例（表 8)

手術施行後良好に経過し, 退院し得た胃癌以外の悪性 患症例は，表 8 亿示寸如人，直腸癌10例，結腸癌 6 例 の消化器癌を中心に42症例に検索を行なった，各症例の 榆査結果は表の如く，T-cell 50〜 75，B-cell 22〜52の 籍围で，その平均值は T-cell $65 \pm 6$, B-cell $34 \pm 6$ と 胃癌同様, 良好な値を認めた。

\section{4. 悪性疾患悪海犋应例}

覀性質に宿いった悪性疾患症例についても胃癌及び胃 癌以外の覀性疾患とにわけ検索した。

\section{1）胃癌症例（表 9)}

悪夜質に宿いった胃癌症例は66例について检索を行な ったが，治瘳切除例は 1 例の及であった．他は，非治瘾 切除例や腫瘍摘出む不可能であった症例，手術の適応が 認められなかった症例及び再発をきたした症例で，胃癌 進行度も全て stage III IVの進行癌であった。

各症例の検查結果は表 9 の如く, T-cell は33〜79の広 範囲にあり，B-cell む21〜79の算囲に認めらんる。その 平均は T-cell $50 \pm 10$ ，B-cell $49 \pm 12$ と健康人比乙著 明に T-cell 低下，B-cell 上昇が認められ，標準偏差值 も著しく增大していた。

2）胃癌以外の悪性疾患症例（表10）

悪性質に楩いった胃癌以外の悪性疾患症例は，表10に 示寸如く，種々の悪性疾患 52 症例について検索した。 


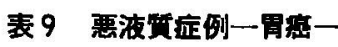

平均値 T cell $50 \pm 10$

\begin{tabular}{|c|c|c|c|c|c|c|c|c|c|c|c|}
\hline Stage & 诂 & $T$ & 8 & Stage & 洁 & $T$ & $\mathrm{~B}$ & Stage & 治 & $T$ & B \\
\hline [1] & 治 & 45 & 58 & N & 非 治 & 40 & 58 & N & $P$ & 35 & 65 \\
\hline & 非 治 & $\begin{array}{c}52 \\
71\end{array}$ & $\begin{array}{l}46 \\
30 \\
30\end{array}$ & ". & & $\begin{array}{l}40 \\
67\end{array}$ & $\begin{array}{l}63 \\
33 \\
33\end{array}$ & & $"$ & 49 & $\begin{array}{l}54 \\
36\end{array}$ \\
\hline 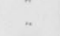 & . & 68 & 30 & . & . & 50 & 51 & " & 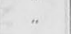 & $\begin{array}{l}\mathbf{r}^{-4} \\
39\end{array}$ & 65 \\
\hline " & . & 52 & 47 & " & " & 42 & 54 & & " & 54 & 42 \\
\hline & " & 70 & 26 & " & " & 49 & 49 & & " & 35 & 63 \\
\hline " & 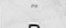 & 41 & 55 & " & " & 36 & 60 & " & $"$ & 36 & 60 \\
\hline & $P$ & $\begin{array}{l}63 \\
56\end{array}$ & $\begin{array}{l}35 \\
41\end{array}$ & 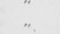 & $"$. & $\begin{array}{l}50 \\
41\end{array}$ & $\begin{array}{l}50 \\
57\end{array}$ & & .. & $\begin{array}{l}51 \\
56\end{array}$ & $\begin{array}{l}50 \\
46\end{array}$ \\
\hline N & 非 治 & 50 & 44 & - & P. & 60 & 33 & 手術 & 世す & 56 & 48 \\
\hline 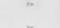 & 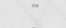 & 48 & 48 & 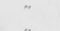 & 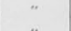 & 50 & 53 & & 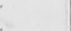 & 33 & \\
\hline . &. & 54 & 50 & .. & . & 50 & 48 & & . & 49 & 53 \\
\hline & & 58 & 43 & & " & 50 & 49 & & & 56 & 46 \\
\hline " & . & 55 & 41 & " & " & 37 & 63 & & 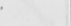 & 57 & 43 \\
\hline & " & 44 & 57 & 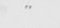 & $"$ & 37 & 63 & & & 57 & 47 \\
\hline 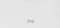 & 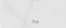 & $\begin{array}{l}54 \\
68\end{array}$ & 30 & . &. & 39 & $\begin{array}{l}60 \\
45\end{array}$ & & & $\begin{array}{l}59 \\
40\end{array}$ & 40 \\
\hline$\sim$ & . & 79 & 21 & * & .. & 36 & 60 & & & 49 & 55 \\
\hline & & 59 & 42 & 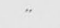 & & 49 & 51 & & & 56 & 38 \\
\hline - & " & 53 & 46 & " & " & 45 & 54 & 他院手 & 析再発例 & 39 & 70 \\
\hline 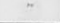 & & 49 & 51 & 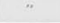 & " & & 46 & & & 48 & 50 \\
\hline
\end{tabular}

表10 悪洨質店例一胃癌以外の癌一

平均値 $\mathrm{T}$ cell $51 \pm 9$

\begin{tabular}{|c|c|c|}
\hline \& & $T$ & B \\
\hline 睡 雷 & 42 & 58 \\
\hline & 56 & 46 \\
\hline " & 39 & 68 \\
\hline " & 53 & 46 \\
\hline$"$ & 59 & 34 \\
\hline$"$ & 52 & 52 \\
\hline " & 64 & 38 \\
\hline " & 43 & 56 \\
\hline " & 55 & 45 \\
\hline 子宮筫 & 45 & 49 \\
\hline " & 41 & 60 \\
\hline 肝艒 & 77 & 28 \\
\hline$"$ & 46 & 55 \\
\hline 䏣のう萿 & 41 & 60 \\
\hline , & 48 & 53 \\
\hline " & 50 & 46 \\
\hline " & 51 & 39 \\
\hline 回盲部富 & 48 & 52 \\
\hline
\end{tabular}

\begin{tabular}{|c|c|c|}
\hline 疾息名 & $T$ & B \\
\hline 道穑 & 67 & 28 \\
\hline " & 69 & 27 \\
\hline " & 42 & 61 \\
\hline$"$ & 51 & 45 \\
\hline$"$ & 55 & 46 \\
\hline 結闻 & 51 & 43 \\
\hline 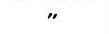 & 38 & 60 \\
\hline " & 31 & 64 \\
\hline " & 74 & 30 \\
\hline 直溲蝠 & 56 & 41 \\
\hline & 63 & 39 \\
\hline " & 42 & 61 \\
\hline$"$ & 47 & 53 \\
\hline " & 55 & 46 \\
\hline 柤 & 55 & 48 \\
\hline & 34 & 63 \\
\hline " & 46 & 60 \\
\hline ״ & 41 & 60 \\
\hline
\end{tabular}

\begin{tabular}{|c|c|c|}
\hline 瘙怠名 & $T$ & B \\
\hline 肺 & 40 & 56 \\
\hline " & 53 & 51 \\
\hline " & 51 & 45 \\
\hline " & 48 & 47 \\
\hline " & 51 & 49 \\
\hline$"$ & 53 & 59 \\
\hline$"$ & 49 & 44 \\
\hline 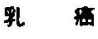 & 56 & 48 \\
\hline " & 56 & 40 \\
\hline " & 54 & 46 \\
\hline " & 47 & 49 \\
\hline 腷 $\mathrm{I}$ & 44 & 58 \\
\hline 覀性リン八 & 55 & 4 \\
\hline 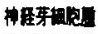 & 56 & 44 \\
\hline 湅桐肉眐 & 49 & 52 \\
\hline 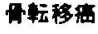 & 73 & 34 \\
\hline
\end{tabular}

各症例における検查結果は, T-cell 31〜77, B-cell 27〜68々胃癌同様, 広範团に認められ，その平均値 は T-cell $51 \pm 9$, B-cell $50 \pm 10$ と健康人に比し,ここです T-cell 低下, B-cell 上昇及び摽準偏差值の増大は顕著 であった。

\section{5. 術前検查值からみた手術根治度}

手術施行前に検索を行なった胃癌症例及び，胃癌以外 の悪性疾患症例の検查結果を手術根治度。即ち, 治窑切 除群・非治窖切除群・切除不能群とにわけ，検討を加え t.

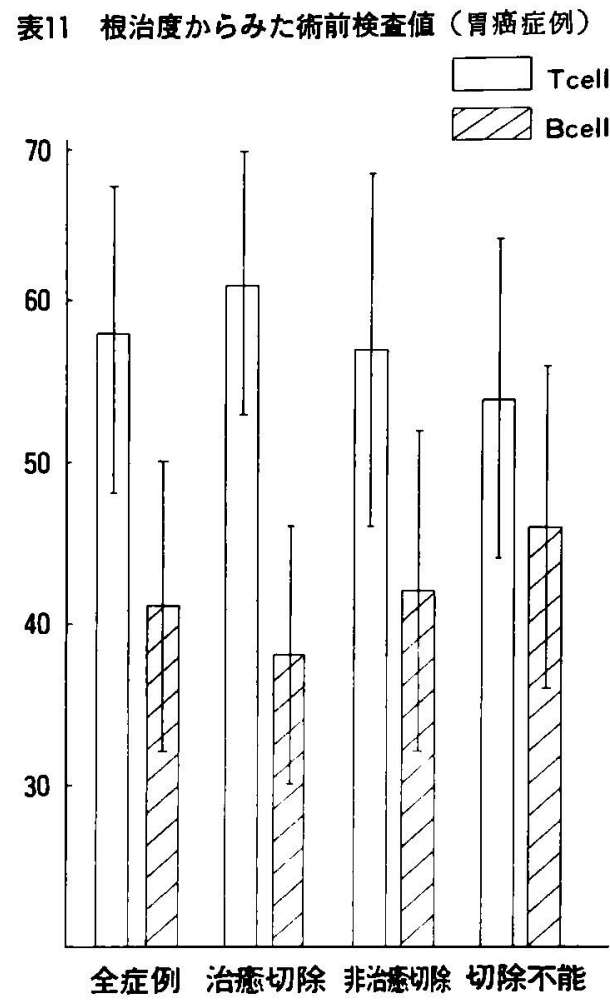

1）胃癌症例（表11）

術前に検索を行なった胃癌症例は治瘾切除33例, 非治 疮切除33例及び切除不能20例の計86症例で, その平均值

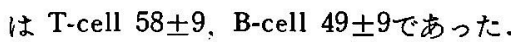

a ) 治癒切除群

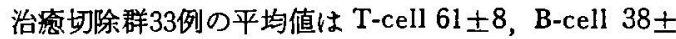
8 でT-cell は健康人に比し，やや低下の傾向はある が，殆んどの症例が正常範囲内に認められた。

b ) 非治痛切除群

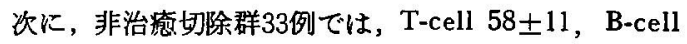
$42 \pm 10$ と，T-cell は正常範囲内より低下し，そのバラッ キの範围む大きくなり，逆に，B-cell が上昇傾向にあっ た。

c ) 切除不能群

T-cell 低下, B-cell 上昇の㑯向は切除不能群では更

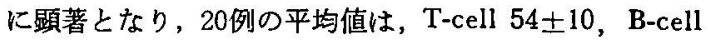

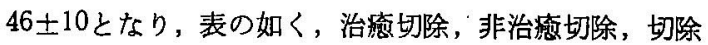
不能となるに従い，T-cell は階段状に低下し，B-cell が 上昇する㥧向にあった。

2）胃癌以外の悪性疾患症例（表12） 


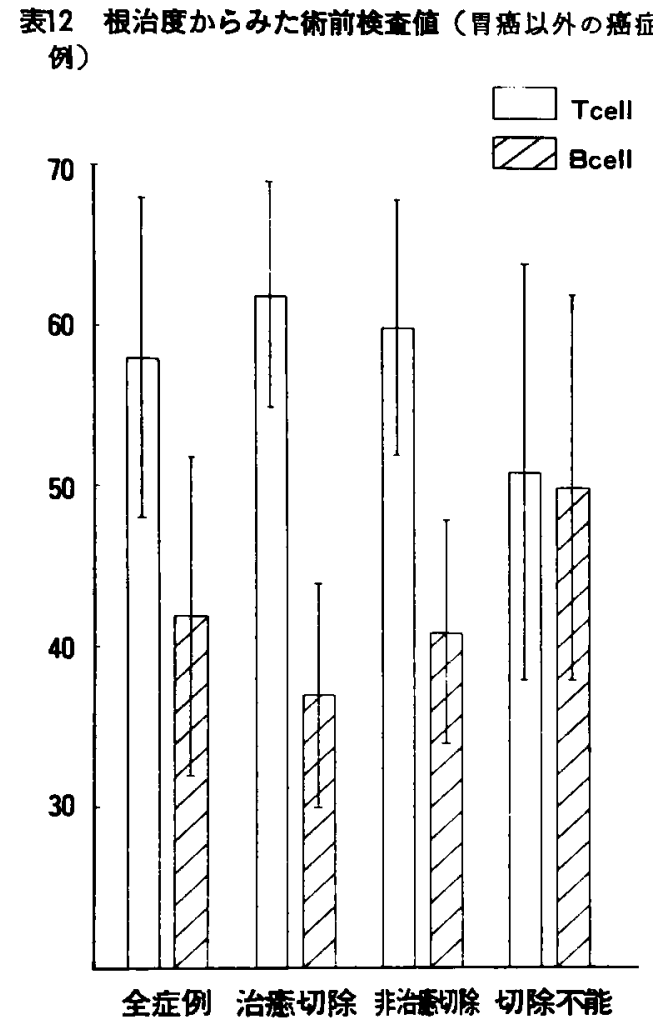

胃癌以外の悪性疾患症例で術前に挨索した症例は，直 腸癌 12 例，結晹癌 8 例，肺癌 9 例等53例であるが，53例

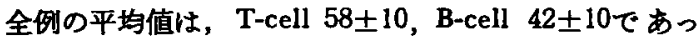
た.

a ) 治察切除群

これを手術根治度別にみると, 治荟切除群19例では，

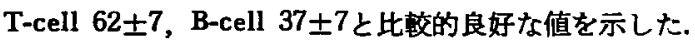

b ) 非治切除群

一方, 非治蒠切除群20例 では T-cell $60 \pm 8$, B-cell $41 \pm 7$ と T-cell 低下の㑯向がみられた。

c) 切除不能群

この T-cell 低下の㑯向は, 切除不能群14例では更に 著明となり，T-cell $51 \pm 13 ， B$-cell $50 \pm 12$ ，胃媳同 様，漂準偏差值の増大，T-cell の階段状低下が認められ た。

以上，根治度からみた術前検查值は，胃癌及び胃癌以 外の悪性疾患症例ともに同様の傾向が認められ，手術根 治度と T・B 細胞此は相関性を示した。

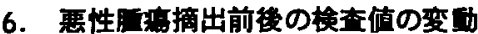

隀場摘出前後の T-cell 值の変動を，胃癌及び胃癌以

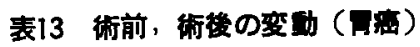

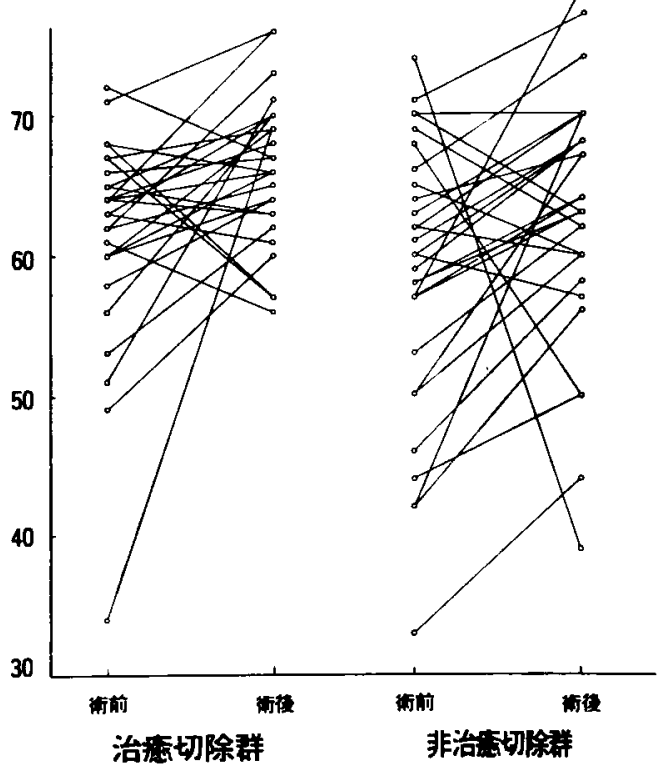

外の悪性疾患症例とにわけ，それを更に治庶切除群と非 治䓌切除群とで比較険討した。

1）胃癌症例 (表13)

胃癌症例で手術前後に検索を行なった症例は，治空切 除群29例，非治等切除群29例の合計58例で，その变動を 表13に示した。

a ) 治空切除群

治虑切除群29例の術前の T-cell 值は34〜72の範囲に 認められたが，その大多数は50〜70の間にあり平均値は 62士 7 であった．手術により腫湟を完全に摘出した後 は，56〜76の範囲に認められ，平均值は66土 5 と上昇 し，標準偏差值す小さくなり，表に示す如く，術前広範 囲に認められた各症例の值が，很後，正常範囲内に集ま ってくるのが認められた.

b ) 非治复切除群

一方, 非治恚切除群では術前の T-cell 值は, 33 74 の広範围に散在し，その平均值は58土 9であった。そし て腫瘍は摘出したが，根治は不能であった術後をみる と，平妁値は62土9上上昇はしたものの，各应例におけ る值は38～79と依然として広籍囲に散在し，治密切除群 の如く，正常範囲内に集中していく傾向はなかった。

2）胃癌以外の悪性疾患症例（表14）

術前，術後の比較を行なった胃瘦以外の悪性疾患症例 は, 治疮切除群, 非治空切除群ともに17例である。 


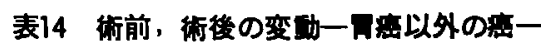

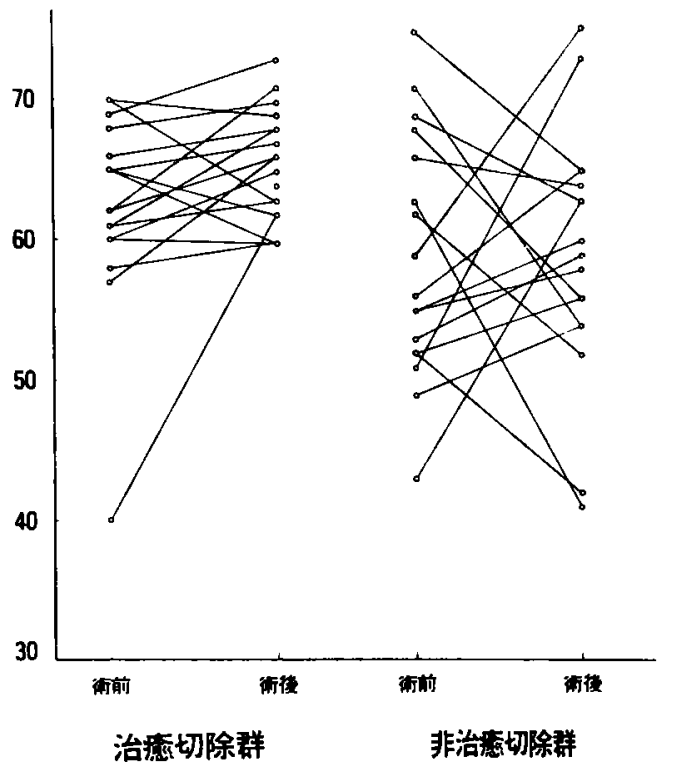

表15 周密手術挠長期生存例

\begin{tabular}{|c|c|c|c|c|c|}
\hline No & 衍后年数 & 㳔别 & Stago & Tcell & Bcell \\
\hline 1 & $14^{7}$ & 우 & III & 73 & 25 \\
\hline 2 & 10 & $\hat{o}$ & III & 68 & 27 \\
\hline 3 & 10 & 우 & II & 72 & 29 \\
\hline 4 & 10 & $\hat{\delta}$ & II & 65 & 30 \\
\hline 5 & 9 & 우 & II & 70 & 26 \\
\hline 6 & 9 & $\hat{\delta}$ & III & 68 & 29 \\
\hline 7 & 9 & $\hat{\delta}$ & III & 60 & 41 \\
\hline 8 & 9 & q & III & 68 & 33 \\
\hline 9 & 9 & 우 & II & 66 & 32 \\
\hline 10 & 7 & $\hat{\delta}$ & II & 67 & 27 \\
\hline 11 & 6 & tิ & III & 73 & 26 \\
\hline 12 & 6 & 占 & III & 71 & 29 \\
\hline 13 & 6 & $\hat{\delta}$ & III & 62 & 36 \\
\hline 14 & 5 & $\hat{o}$ & II & 71 & 31 \\
\hline 15 & 5 & 우 & III & 66 & 35 \\
\hline & 平 & 均 & 值 & $68 \pm 4$ & $30 \pm 4$ \\
\hline
\end{tabular}

a ）治度切除群

治疹切除を行なった17例の術前の T-cell 值は40〜70

|の範囲にあり, 術前より正常範囲内にある症例か治んど で，平㚬値は62土 7 であった．㭪後は全症例が良好な值 を示し，60７3の範囲にあり，平㘬值も65士4 と健康人

1 と同様，良好な值を示した。 b ) 非治病切除群

一方, 非治病切除例では, 術前の T-cell の平均值は $60 \pm 8$ であったが, 各症例の值は43〜75の広範囲に散在 していた. 術後も, 術前検査值の低い症例で上昇を認め たものの，正常範囲まで回復する症例は少く，また，術 前高い值を示していた症例が術後低下をきたしたりした

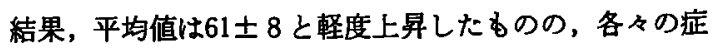
例は41〜75と依然として広範囲に散在していた。

\section{7. 胃空術後辰期生存应例検查值（表15）}

東京医大病院で胃癌手術を受け，5年以上を経過した 患者15例を無作為的に選択し, T.B 細胞比の検索を試み た。

その結果, 術後最高 14 年, 最低 5 年以上を経過した長 期生存患者15例の検査結果は，表15に示す如く，T-cell 60〜73, B-cell 25〜41の範囲にあり, 平均値は T-cell $68 \pm 4$, B-cell $30 \pm 4$ と良好で摽準偏差值む小さく， ： ラッキの少い事を示した。

\section{IV. 考案}

\section{1. 細胞性免㾤能としての T-cell}

生体の防禦機構は種々の要因により成立している.分 化の進んだ動物では, 特異的な抗体, または, リンパ系 細胞の働きにより，外敵を排除する巧妙な機構に負らと ころ大であり，この特異的免疫反応系には，体液性免疫 と細胞性免度で代表される.

18世紀末の Edward Jenner の種痘から始まった免疫 現象の研究は, 感染症に対するむのであり，細菌と血清 中の $\boldsymbol{\gamma}$-グロブリンとの免疫現象として発展してきた。 即ち， $\gamma$-グロブリンが抗体として体液中を流れ，異物抗 原と特異的に反応し，これを除去する体液性免度であ る.そして，1950〜60年代に $\gamma$-グロブリンの分子構造 が解明され，IgM，IgG の構造決定をみるよらになり， 感染症の疫学及び，治療に重大な影響を与えた。

また，一方では，この体液中を流れる $\boldsymbol{\gamma ー ク ゙ ロ フ ゙ リ ン ~}$ といら物質たけでは解決できない免疫現象む古くから知 られている. Landsteiner and Chase ${ }^{13)}$ は，1942年に遅 延型過敏反応が，血清抗体の移入ではなく，生きたりン バ系細胞の移入により，受身伝達ができる事を示した。

これ以来, 体液性免疫の他に, 生きな感作りンパ系細胞 に传存する免疫反応が想定され，今日，体液性免疫が B 稩胞系に担われ，後者は，紐胞性兔疫と呼ばれ， $\mathrm{T}$ 細胞 釆に担われているとされている。

この細胞珄免疫能の発現, 即ち, 抗原の認識, 抗体の 産生, 標的細胞の障害等は，単一の免疫因子で完成され 
る事は不可能で, T-cell の他に B-cell、 マクロファージ 等の免疫担当細胞が相互に関連し，その作用をなしてい るものと考えられる(10)16) 16)。

兔疫に関与寸る免疫担当細胞については，兔疫反応そ のものが非常に複雑で，しかも，反応過程で，その役 割, 分担を異にする細胞がある. その分類については,

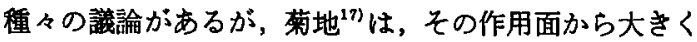
3つに分けている.（1）抗原受理及び抗原情報伝達細 胞（2）情報受理及び反応細胞（3）免疫遂行細胞であ る.これらの作用を行ら細胞には，T-cell，B-cell，マク ロファーシ，単球，好中球，好塩基球等多種にわたってい， るが，最む重大な働きを行らのが T-cell である.T-cell は細胞珄免疫能の主役として種々の働きをなし，その作 用により下記の如く分類されている.

a) helper T-cell : B-cell が抗原と反応して抗体産生 細胞に分化・成熟するのを助ける。

b) killer T-cell : 癌細胞の障害等, 直接標的細胞を 障害する。

c） amplifier T-cell：抗原と接触して幼若化し，増殖 して killer T-cell の作用を増幅する.

d) suppressor-T-cell : killer T-cell の働きを抑制した り，B-cell の分化成熟を抑制して，抗体産生を妨げる。

e ）抗原と T-cell の反応によって種々のリンフォカ インを産生し，マカロファージの活性化・遊走性に作用 する。

以上の如く，免疫担当細胞としての T-cell は多種の 働さをなすといわれている．著者はこの様な T-cell の 免疫細胞としての重要性を認識し，悪性疾患患者の T-cell を追求する事により，患者の治栫面及び予後の面 での推測が充分可能であると考えろ。

\section{2. リンパ球識別用キットの罗当性}

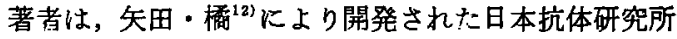
製ヒトリンパ球識別用 $\mathrm{T}$ 細胞・ B 細胞微量测定用キット を用いて検索を行なった．同キットを用いての末梢血 よりのリンハ球分離法は比重遠心法であるが，その他の リンパ球分離法としては, fiber column 法がある。これ は，ナイロンガラス綿維に末梢血を通過させて，粘着性 を有する顆粒球，単球を線維に附着させ，リンパ球と赤 血球を分離する万法である、しかし，この方法では一部 の粘着性の強いリンパ球を同時に失うことになる．こと に，B-cell や活性化されたT-cell は粘着性があり，失 われやすいこのため，T-cell と B-cell の量的関係を 知る事が目的である本研究には不向きである，一方，著
者が行なった比重遠心法は, リンバ球と他の細胞との比 重が異なる事を応用した方法で，遠心により，比重の高 い赤血球と顆粒球は下圆に沈降し，リンパ球及び単球， 血少板が血漿成分との中間に認められる.この方法によ っても，一部の比重の高いリンパ球を失う可能性はある が，リンパ球の回収率が70\%以上である場合には，T ・

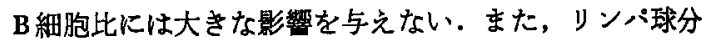
画には単球の泥入があるが，これはペルオキシダーゼ 染色を行う事により同定が可能である ${ }^{18)}$.

末梢血より分離 したリンパ球を T-cell ・ B-cell の subpopulation に分ける 万法としては，両細胞の物理的 性質の相違を利用して，下記のような方法が従来行なわ れていた（1）密度勾配遠心法，（2）細胞電気泳動 法，（3）速度沈降法，これらの方法は，手技が繁雑な らえ，両細胞の population の完全分離は不可能で，デ 一ター的に精度が落らる事は否定できない199. 著者が用 いたキットは，T-cell，B-cell の生物学的活性により， 異なったマーカーを用いて識別する方法である．即ち， T-cell はヒツシ赤血球と特異的に反応して rosette を形 成する性質があるのに対し，B-cell は細胞表面に補体 レヒプターが存在し, 19S 抗体補体感作赤血球と補体結 命反応を行う事により rosette を形成する．故に，ヒツ ジ赤血球及び補体感作ヒッジ赤血球を用いる事により， T-cell ・ B-cell の識別が可能であり, 著者の目的に合致 し，かつ，手技が簡便なので同キットを使用した。

\section{3. 健康人の T-cell 值}

健康人16症例30檢体に拈ける検査結果は，T-cell 57〜 71, B-cell 26〜49の範囲で, 平均值は T-cell 65士4, B-cell 35士6であった。これは，表 5 に示した如く，本 邦に括行る檑の T-cell 60〜70，B-cell 30〜50，矢田の T-cell 40 60, B-cell $20 \sim 30$, Ross $の$ T-cell 65, B-cell 35, William の T-cell $75 \pm 15$, B-cell $23 \pm 7$, Wybran の T-cell 62〜73に比し大差なく, T-cell 65士 4, B-cell 35士6を正常値とした.

\section{4. 良性疾悤の T-cell 值}

良性疾患で仕健康人とほぼ同様の值を示したが，黄㾝 陽性例, 沉発性腹膜炎例において，T-cell 值の低下がみ られた。

1) 黄疸陽性例について

良性疾患中，黄疸陰性例に淤ける平均值が，T-cell 64 \pm 5 , B-cell 36士7 であるのに 対し，黄㡺陽性例におい ては，T-cell 55士8 と著明な低下がみられた。この黄疸 における T-cell 值低下について，山本ら ${ }^{20)}$ は，急性肝 
炎 9 例，遷延性肝炎11例，慢性肝炎12例，旰硬变21例に ついて検索した結果，正常人に比し14〜21\%の T-cell 値の低下を認めている．この原因について彼等は，肝の 病巣局所への T-cell の動員による末梢血中の T-cell 比 の低下，及び肝疾患患者血清中には T-cell 細胞膜表面 にあると考えられるヒッジ赤血球のりセプターをブロッ クする因子が含まれており，それに対する T-cell 值の 低下ではないかと述へてている。

また，中川ら ${ }^{211}$ 恃，急性ウィルス性肝资の治漂延中 慢性化について，Au 抗原と感染兔疫及び自己兔疫性疾 患の見地からリンパ球についての検索を行なっている。 その結果，慢性肝炎で19例中 9 例，肝硬変で13例中 9 例，自己免疫性肝炎で4例中 3 例に T-cell の低下を認 めている、彼等は，この原因を肝炎のウイルス感染とし てとらえた場合には，他のウイルス疾患と同様，ウイル ス增殖によるリンパ球破壊，感染によるリンパ球の局所 動員，ウイルス感染細胞の放出物質によるリンパ球の機 能障害等のリンパ系障害が T-cell に強く作用している のではないかと推測している．また，自己免疫疾患とし て肝咨をとらえた場合は， suppressor T-cell の久除， helper T-cell の出現による B-cell の増加と同様の機序 で T-cell 值の低下をとらえている。

また，川合ら ${ }^{22)}$ b，慢性肝炎12例，旰硬変21例におい， て T-cell 值を求め，慢性肝炎で7.2\%，肝硬变で7.4\% の T-cell の低下を認め, ${ }^{3} \mathrm{H}$ tymidine の取り込みによ る PHA 幼若化率についても検索し, 慢性肝炎で28例中 10例，旰硬变で57例中26例に T-cell の反応低下を認め ている.この原因については, 山本らと同様, 病巣局所 への T-cell 動員, 血清中の T-cell 抑制因子の存在と ともに, ウィルス感染も T-cell 值低下の一因としてい る.

上記の如く，黄㾞患者の T-cell 低下の原因は，原疾 患の病態のとらえ方により，各研究者にも解秎の相違が あり，更に検討がなされている過程である．著者が検索 を行なった症例についても，肝病巣への T-cell 動員， 血清中の T-cell 抑制因子，ウイルス感染による $\mathrm{T}$ 細胞 系の障書などが複雑に交錯しているのではないかと考え られる。

2）汎発性腹膜炎症例について

著者が検索を行なった汎発珄腹膜炎患者のうち，黄㡺 を併発しなかった 4 症例の T-cell の平均值は58土 6 と 比較的健康人に近い値を示しているのに対し，B-cell 值 は44土5 と上昇が著明である.T-cell 值低下の原因とし
ては，矢田 ${ }^{23)-25)}$ が述べる如く，重症感染症における胸 腺退縮の影響，化脤菌の感染防禦に対する B-cell の 相対的増加，あるいは，長期の食事摄卭不能による栄 養障害等が考えられられるが，著者の検查結果からは， B-cell の相対的增加が主原因ではないかと思われる。

以上の様に, T-cell 值は黄疸及び広汎な炎症により， 大きく左右される事が考えられる. 悪性疾患においてる 同症状を併発した場合は同様であろうし，今後の検索に ついは臨床症状，椧査データーを充分把捯し検索しな ければ, 実際の生体免疫能とはかけはなれたるのを観察 している可能性を示唆している。

\section{5. 悪性疾思経過良好症例の T-cell 值}

経過良好で退院した悪生疾患患者の T-cell 值は，胃 癌症例で $65 \pm 5$, 胃癌以外の悪性疾患症例で $65 \pm 6$ と健 康人とほぼ同様であった。ここで, T-cell 值が60以下に 低下している症例は，胃癌患者では57例中 7 例の $12 \%$ ， 胃癌以外の悪性疾患では42例中 7 例 $17 \%$ に認められ る.このらち, 胃癌症例を個々に㭘討すると興味ある事 㬰が認められる. 即ち, T-cell 60以下の症例は早期癌 ほど多く17例中 4 例 (24\%) と高率を示し, 治空切除例 20 例中 2 例 $(10 \%)$ 非治芴切除例20例中 1 例 $(5 \%)$ と 癌の進行と反比例した. この事実に対する解釈を随伴性 免疫説 ${ }^{26)-30)}$ で理解する研究者むいる. 即ら, 担癌生体 は癌抗原と生体中の抗体がバランスを持って存在してお り, 癌增殖が一定度以上に達する以前の時期（例えば早 期癌）に充分な抗原量が得られず，担癌生体の免疫力む 不充分である．この時期（誘導期）に腫瑒が摘出される と，逆に免度力が低下するとの説である。この説である 程度の理解はできるが, 随伴性免疫説は, また確立され た理諭ではないし，他の手術侵襲に由来し T-cell の低 下をきたした事も否定できないので言明はさけねばなら ぬと考光る.しかし，随伴性免疫説については，今後， 更に詳細な検討がなされる必要があるらし，またここの 様な症例については，臨床的にす種々の面から観察を行 い, 再発予防のために免疫療法，化学療法など有効な処 置を施すよう念頭におく必要があるであろう。

いずれにしろ，著者が検索した経過良好症例では，胃 癌症例でも胃癌以外の悪性疾患症例でる，T-cell 值怔 常範囲内にある症例が多く，腫瘍に対する生体の防禦機 構は，ある程度保たれていると思われる。

\section{6. 悪性疾患悪洨留症例の T-cell 值}

悪液質に陌いった症例の T-cell 值は，胃癌症例で50 \pm 10 , 胃癌以外の悪性疾患症例で $51 \pm 9$ 上健康人に比し 
大きく低下し，経過良好例と比較してもその差は䫒著 で，生体に扩ける細胞性免窪能の低下を示唆している。 しかしながらここです健康人と同様，良好な值を示し た症例が胃癌患者で66例中10例（15.2\%）飞認められ， 胃癌以外の悪性疾患症例でも52例中 7 例 $(13.4 \%)$ 飞み られた.この T-cell 值が良好であったにもかかわらず， 悪液質に宿いった17例について，著者はその T-cell 機 能が問題ではないかと考えている. 即ち, count された T-cell が, 腫瘍を直接障害する killer T-cell p helper T-cell であるのか，更に，免疫抑制に働く suppressor T-cell が主役をなすのがより，解积が全く異るからで ある。

これら T-cell subset の識別法として，麦谷ら ${ }^{311}$ は, suppressor T-cell と, 一部の killer T-cell には IgG の Fc 受容体が存在し helper T-cell は, IgM の受容体を有 し，IgG 受容体が欠除している事に着目し，ヒッジ赤血 球 rosette 形成リンパ球に, 更に, ニワトリの赤血球を 反応させ double rosette formation を形成させ，癌患者 のリンバ球の動態を観察している．その結果，進行癌患 者では double rosette を形成している症例が多いと報告 し, suppressor T-cell が double rosette の主役であるら と推測している。これら17例の T-cell の主体が細胞性 兔疫中抗体産生に対して抑制的に働く suppressor T-cell であれば理解できるし， killer T-cell ゃ helper T-cell が主体であれば，これらの症例では随伴性免度が存在し ていると考えられる。この識別法は，この様な症例では 大きな研究課題として注目され，今後，追試されねばな らぬ大きな問題といえる。

更に, リンバ球の機能面の検索方法に PHA 幼若化率 の測定中，MIT が常用されているが，これらの症例に おけるリンパ球が免疫機能を有するか否かを知る事る重 要な問題である. 今後,これらの検査との併用も必要で あると考えている。

\section{7. 術前娭查值と手術根治度について}

術前に検索を行なった症例の T-cell 值を手術根治度 別にみ万と，胃癌症例でも胃癌以外の悪性疾患症例でも 治窑切除, 非治港切除, 切除不能と手術根治度の低下と とすに T-cell 值す低下していた。

この術前検查値と癌の進行度に関して，T・B 細胞比 と PHA 幼若化率について検索を行なった小林ら ${ }^{32}$ 住,

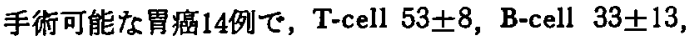
幼若化事 $46 \pm 15 \%$ であるのに対し，手術不能な進行胃癌 16例では T-cell $50 \pm 9$, B-cell $36 \pm 11$, 幼若化率 $52 \pm 16$
$\%$ と， T・B 練胞比は悪化しているのに対し, 幼若化率 は一定の相関を示していないと報告している。

以上の結果より著者は, 癌の進行度は $\mathbf{T} \cdot \mathbf{B}$ 細胞比の 面からある程度推測可能であり，同時に術前の手衍根治 度についての一指標になるすのと考光る。

8. 怔演摘出前後の T-cell 值について

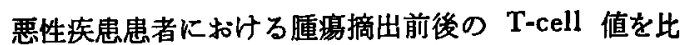
較してみると，治瘾切除を行なった症例では，胃癌症例 でも胃痁以外の悪性疾患でも術後 2 週間以内に正常篹团 内に回復する症例が多数みられた。一方, 非治空切除に 終った症例では，術後の T.cell の平均値は上昇して る, 個々の症例の值は広範囲に広がり, かつ, 術前低值 であった症例が術後正常範囲内まで回復する应例は少な かった.な拈，著者は手術直後にも $\mathbf{T} \cdot \mathbf{B}$ 細胞比の検索 を行なってみたが，生体に対し很後侵咅が残っているた め，白血球增多が認められ，リンバ球層への顆粒球混入 す多く，一定の㑯向は認められなかった。故に，細胞性 免疫能の検索には，術後侵埕の回復したと思われる術後 1 週間以降が適当との結論を得, 以後の検索は街後 $1 \sim$ 2 週間の間に行なった。

術前・術後の細胞性免度能の比較に関して折田 ${ }^{33}$ は, 術前之術後 3 週間に批りるPHA 幻若化率について検 討を行なっている，その結果，良性疾患では変動を認め ず，悪性疾患治痹切除例35例では，術前平均幼若化率が $52.5 \%$ でり，術後 3 週間目では $57.5 \%$ と上昇の傾向が あるのに対し, 非治等切除27例では術前から34.4\% と低 値であったものが術後 $28.8 \%$ と更に低下していると報告 している.

このよらな結果から治庱切除を行い得た症例では， T-cell の腫湯監視機構, 障害機構は回復していると推测 されるに対し，非治瘾切除症例では，生体は依然として

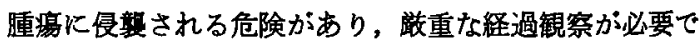
あろち。

\section{9. 冎程術後長期生存例について}

胃癌手術後 5 年以上を経過した長期生存患者 15 例飞和 ける T-cell 值は，66〜77の籁囲にあり，平均值は68士 4 とすべて良好で，尰煬に対するリンパ球の認識機構， 抗体産生機構，障害機構は充分保持されていると推測ざ れる.

このよらな結果から，今後，悪性腫痬の手衍を施行し た患者に対し， T・B細胞比を中心とした免疼学的検索 を行ら事は長期の治療効果を得るために必要な事である と考える。 
著者は，悪性疾患患者に扰いて T ・ B 細胞比を椧索す る事は有意義であると，既汇発表している 結果からる, 細胞性免疫. 即ち, 腫湯免淩能の第 1 歩と してT・B細胞比を求める事は意義の有る事である。そ して，霹35 す患者の免疫機能を適格に表現し得ないが，治療に伴う 変化などを観察する臨床検查法として有効であると述べ ている.故に，これを释時的に観察する事は，臨床症状 の推移，予後の推測には有意義である之考える. 今後, 更に逮延型皮内反応を中心てした各種パラメーターを加 光，PHA 幼若化率を中心としたりン・球の機能面の検 索を行い，また，T-cell の各 subset の明解な分析が可 能となり，癌細胞の培養面の進歩とともに，癌特異抗原 の研究がなされていくならば，癌の免疫療法は治療面で より有効な手段となっていくであるら。

\section{V. 結 語}

胃癌患者を中心として要性疾患患者のリンパ球 subpopulation を識別して， T ・ B 細胞比を求め, これを臨床 症状の推移とともに観察し，予後の面を中心として梌討 し，下記の結諭を得た。

1）経過良好な悪性疾患患者の $T \cdot B$ 細胞比は，健康 人とほぼ同様であった。

2）悪夜質に宿いった症例では，著明な T-cell の低 下が諗められた。

3）手術根治度の低下とともに，T-cell 值も低下する 傾向を示した。

4）治癋切除，非治瘾切除を問わず，腫韵摘出により T-cell 值は上昇する傾向を認めたが，治瘾切除例は正常 範囲内儿復する症例が多い。

5）胃癌術後 5 年以上の長期生存患者では，健康人と 同様良好な値を示した。

6）以上の事より，T・B 細胞比は，経時的炕観察す る事により，覀性疾患患者の予後判定に有効な指標とな る.

稿を終るにあたりここ校閞をいただいた恩師牧野惟義 教授に深く感謝の意を表します。また，本研究にご理 解，こ援助を睗った永井純義教授に感懒致すととむに， 䅂始，ご指導ここ教示いただきしした相馬哲夫教授，小 沢靖講師，井上七讙師に深く感謝致します。また，研究 にこ協力いただきしした教室諸先生方にる心から感謝致 します。

なお，本論文の要旨は下記学会に於いて発表した。 第95回 東京医科大学医学会総会
第61回 日本消化器病学会総会

第74回茨城外科集談会

第13回 日本瘦治療学会総会

第 7 回 日本消化器外科学会大会

第82回茨城外科集談会

参考文献

1) 菊地浩吉: 免疫の 概念と歷史, 医科免疫学, 1-13, 南江堂, 1976.

2）菊地浩吉：細胞性免疫，医科免疫学，149-169, 南江堂, 1976.

3）北川正保：免疫反応浙ける抗原構造と抗原の 役割，代謝，12：51一59，1975.

4）矢田純一：免疫応答に拔ける T-cell と B-cell. T ソンバ球と B リンパ球, 73-125, 中外医学 社, 1974.

5）橋本嘉幸：生体の抗原認識. 畽場免疫学, 181一 188, 朝合書店, 1974 .

6）野本亀久婎：胸腺 の 役割. 腫瘍免疫学, 188一 192, 朝倉書店, 1974 .

7) Mitchell, G.F., Grumet, F.C. and Mc Devitt, H.O.: Genetic control of the immune response J. Exp. Med., 135: 126-135, 1972.

8) Baker, P.J., Stashak, P.W., Amsbauch, D.F., et al.: Evidence for the existence of two functionally distinct types of cells which regurate the antibody response to type III Pneumococcal polysaccharide. J. Immunol., 105: 1581 $-1583,1970$.

9) Tada, T. Okumura, K.: Cell cooperation in the antihapten homocytotrophic antibody response. J. Immunol., 107: 1137-1145, 1971.

10）青木隆一：Lymphokines. 医学のあゆみ，90： 499-502. 1971.

11) Mitcell, G.F. and Miller, J.F.A.P.: Cell to cell interaction in the immune response. $\mathrm{J}$. Exp. Med., 128: 821-837, 1968.

12）矢田純一，橘 武彦：ヒトリンパ球 Subpopulation の分別. 兔疫実験操作法 II 451-453. 日 本兔疫学会, 1972.

13) Landsteiner, K. and Chase, M.W.: Esperiments on transfer of cutaneous sensitivity to simple chemical compounds. Proc. soc. Exp. Med., 49: 688, 1942. 
14) 矢田純一：A・B・T-cell の相互作用. 医学の あゆみ, $90: 486-493,1974$.

15）菊地浩吉, 石井良文 : 抗腫場抵抗性之細胞性免 疫, 臨床免疫, $6: 913$-925. 1974.

16) 檑 武： $T$ 細胞と B 細胞. 癌と化学療法, 2 : $136-138,1975$.

17）菊地浩吉，森 道夫：免疫に関与する細胞. 医 科免疫学, $24-43$, 南江堂, 1976 .

18）矢田純一：ヒトT-cell, B-cell の同定・測定・ 単難, Tリンパ球と B リンパ球, 50〜 72, 中外 医学社, 1974.

19）矢田純一：免疫反灾における T-cell と B-cell. T リンパ球と B リンパ球, 73-124, 中外医学 社, 1974 .

20) 山本祐夫, 中尾昌弘：肝炎における T-cell, Bcell の異常. 日本臨床, 33:258-263, 1975.

21）中川 潤, 伊藤憲一, 深瀬政市 : 肝炎の遷延之 リンパ球及び細胞性免疫, 臨床免疫, $5: 943$ 950, 1973.

22）川合弘毅，中尾昌弘：肝矮患におけるリンパ 球, 臨床免疫, $7: 497-503,1975$.

23）矢田純一：免疫不全における T-cell, B-cell の 異常, Tリンバ球と B リンパ球, 127-156, 中 外医学社, 1974.

24）矢田純一：T-cell，B-cell と感染症， Tリンピ 球とBりンパ球, 157-175, 中外医学社, 1974 .

25)矢田純一：栄養失調症と T-cell, Tリンパ球と B ソンパ球, 205, 中外医学社, 1974.

26) 小林 博: 癌の免疫療法. 特異的活動兔疫, 尰 湟兔度学, 444-449, 朝會書店, 1974.
27) 後藤田栄貴 : 癌の治療に括ける免疫学的背景, 外科潦法と免疫, 隀瘍免疫学, 427-430, 朝倉 畫店, 1974.

28) Gershon, R.K. and Kondo, K.: Dependence of comcomitant tumor immunity on continued antigen stimulation. J. Nat. Cancer Inst., 46: 1169-1175, 1971 .

29) Green, H.S.N. and Harvery, E.K.: The inhibitory influence of a transplanted hamster lymphoma on metastasis. Cancer Res., 20: $1094-1101,1960$.

30) Gershon, R.K. and Kondo, K.: Mechanism by which the spleen may act in regulaitng tumor immunity after tumor resection. J. Nat. Cancer Inst., 43: 545-551, 1969.

31) 麦谷暒夫, 成木行彦, 矢田純一他 : 消化器悪性 疾患患者の治療に批ける $\mathrm{T}$ 細胞の变化. 日癌治 療会誌, $13: 12-19,1978$.

32）小林良竧, 伊藤賢次郎, 西村ミチ子他：リンパ 球の Subpopulation と幼若化現象からみた担癌 生体の自己防衛能について, 臨床免疫, 6 : 487-492, 1974.

33）折田黄三：悪性腫匐に括ける免疫異常. 兔疫学 からみた尰瘍，197〜218，医学書院. 1975.

34）長田省一，井上 七，相馬哲夫他：悪性疾患 患者に括ける T-cell の動態. 最新医学, 12 : 2361-2367, 1977.

35）槄武彦： $T$ 細胞と B 細胞, 癌と化学療法, 2 : $136-138,1974$. 